\section{Listeria monocytogenes Meningoencephalitis in an Adult}

Brit. med. F., 1965, 1, 634

Listeria monocytogenes, fully described by Murray, Webb, and Swann (1926), is a short motile Gram-positive organism, readily showing pleomorphism on culture. The clinicopathological picture in man is one of septicaemia with local lesions in viscera and the central nervous system (Reiss, Potel, and Krebs, 1951 ; Seeliger and Cherry, 1957). Cases are uncommon, though in the past 10 years increasing numbers have been reported, especially from Germany. The best-known and most dramatic form is a fulminating neonatal type with a high mortality: infection passing from the mother, probably transplacentally. Meningoencephalitis is prominent and usually the cause of death (Sepp and Roy, 1963). Far fewer adult cases have been reported (Didisheim and Meisser, 1963). Here the picture is of a more chronic meningitis with subacute onset. The following case is reported because it illustrates the difficulties of diagnosis in the sporadic case and because without effective treatment mortality may be as high as $50 \%$.

\section{Case History}

A woman aged 39 was referred to hospital because of persistent headache and vomiting following a lymphocytic meningitis.

The original illness had been of rapid onset with severe headache, fever, general malaise, and signs of meningitis. Lumbar puncture had revealed a cerebrospinal fluid (C.S.F.) with raised pressure, a protein of $120 \mathrm{mg} . / 100 \mathrm{ml}$., and cells $380 / \mathrm{c} . \mathrm{mm}$., all lymphocytes. No organisms were found on microscopy or culture. As headaches and intermittent fever had persisted a further lumbar puncture was done a week later. Cells had fallen to 170 . A blood count was normal. She returned home, and during the next month continued to have episodic headaches, occasional vomiting, and probably some pyrexia. She became depressed, listless, and emotionally unstable and required large doses of analgesics and tranquillizers. She was regarded as suffering from a neurotic prolongation of symptoms originally due to a lymphocytic meningitis, but was sent for further neurological examination.

When seen 10 weeks after her initial illness she complained bitterly of episodic severe bursting headaches and evening vomiting. On examination she looked ill and had lost weight. There were no abnormalities in the central nervous system. The radiological appearance of the skull and chest was normal. She was afebrile and remained so throughout the period of observation, apart from occasional spikes of temperature. An electroencephalogram showed a slow-wave abnormality in the left posterior temporal region. Her haemoglobin was $77 \%$ and white blood count 7,600/c.mm., with a normal differential count. The E.S.R. was $4 \mathrm{~mm}$. in one hour. C.S.F. had a protein of $205 \mathrm{mg} . / 100 \mathrm{ml}$. and 64 lymphocytes and 2 polymorphs per c.mm. No organisms were seen and culture was sterile. In view of a possible abscess or other focal lesion in the left temporal region a left carotid angiogram and air encephalograms were done. Both were normal. Examination of blood, stools, and C.S.F. for a range of likely viruses proved negative, and no evidence of brucellosis or leptospirosis was found. A week's course of sulphadimidine and penicillin improved her general malaise and headaches, and her vomiting ceased. However, the C.S.F. remained abnormal with $180 \mathrm{mg} . / 100 \mathrm{ml}$. of protein and 350 cells per c.mm., of which $17 \%$ were now polymorphs. Culture was again sterile. During the next three weeks courses of nitrofurantoin and intrathecal streptomycin made no substantial difference to her C.S.F., where protein varied from 100 to $220 \mathrm{mg} . / 100 \mathrm{ml}$. and cells from 110 to $350 /$ c.mm., with polymorphs always present and sometimes as high as $40 \%$. However, her clinical state continued to improve.

Some five weeks after her admission further culture of C.S.F. grew an organism. It was grown from three separate C.S.F. specimens and was successfully subcultured and identified as L. monocytogenes (type $4 \mathrm{~b}$ ). An antibody titre of $1: 125$ was later found in her serum. She was given a two-weeks course of tetra- cycline, but cells and protein in her C.S.F. remained high. Then after a seven-day course of chloramphenicol a substantial drop in cells and protein occurred for the first time: protein fell to $90 \mathrm{mg} . /$ $100 \mathrm{ml}$. and cells to 45 lymphocytes per c.mm. At this stage she returned home to attend for weekly and later two-weekly lumbar punctures. Oxytetracycline was given for a week, but cells and protein once more increased and a further five-day course of chloramphenicol was given. Thereafter all antibiotics were stopped and the C.S.F. gradually returned to normal. However, it was not until six months after her admission that she was regarded as cured, with the fluid showing $45 \mathrm{mg}$. of protein and 9 lymphocytes per c.mm. She has remained in good health for over 18 months.

\section{Comment}

In this patient prolonged symptoms and emotional and behavioural changes following an acute supposedly viral meningitis were diagnosed as psychogenic because there were no abnormal physical signs and the blood count and E.S.R. were normal. In fact, they were due to chronic L. monocytogenes meningoencephalitis. Cerebrospinal fluid examination readily established that she was suffering from a chronic meningitis, but the localized electroencephalographic changes and the suggestion of fluctuating intracranial pressure raised the possibility of a cerebral abscess. This was excluded by angiography and air encephalograms, but only after some weeks of persistent bacteriological investigation was $L$. monocytogenes isolated from the C.S.F. Growth from three separate specimens and a serum antibody titre of $1: 125$ confirmed the diagnosis.

The search for an effective remedy took a further few weeks. The organism was sensitive in vitro to tetracycline, streptomycin, erythromycin, ampicillin, chloramphenicol, and sulphadimidine and resistant to penicillin and nitrofurantoin. However, penicillin, streptomycin, tetracycline, oxytetracycline, and sulphadimidine failed to produce any substantial improvement in the C.S.F., though with all of these there appeared to be clinical improvement and more prolonged treatment might later have affected the C.S.F. A clear improvement followed a week's course of chloramphenicol, and after a further five-day course slow but steady improvement in the protein and cell content of the C.S.F. continued without further specific treatment. The fluid had returned to normal some four months after the treatment was started, though her general health and well-being had then been normal for some two months. Her "neurotic" symptoms cleared as her general health improved. Chloramphenicol is considered to be a particularly effective antibiotic in this condition (Loda and Sell, 1963), though it is probable that ampicillin will prove equally useful.

Necropsy findings (Sepp and Roy, 1963) show small superficial abscesses indenting the cortex as well as marked and widespread meningitis-a true meningoencephalitis. The macroscopic picture is not unlike that of pneumococcal meningitis. It is probable that the localized E.E.G. changes in this case, which had largely cleared within a month of treatment, represented some such localized cortical pathology.

\section{W. M. WHITTY, D.M., F.R.C.P. \\ J. D. Macaulay,* B.M., B.CH., D.Path. From the Departments of Neurology and Pathology,} United Oxford Hospitals.

- At present Assistant Pathologist, Salford Royal Hospital.

\section{REFERENCES}

Didisheim, J. C., and Meisser, B. (1963). Schweiz. med. W schr., 93, 783. Loda, F., and Sell, S. H. W. (1963). Sth. med. F. (Bgham, Ala.), 56,

Murray, E. G. D., Webb, R. A., and Swann, M. B. R. (1926). F. Path. Bact., 29, 407.

Reiss, H.' J., Potel, J., and Krebs, A. (1951). Z. ges. inn. Med., 6, 451. Seeliger, H. P. R., and Cherry, W. B. (1957). Human Listeriosis, its Nature and Diagnosis. U.S. Dept. of Health, Education, and Welfare.

Sepp, A. H., and Roy, T. E. (1963). Canad. med. Ass. ¥., 88, 549. 